\section{- \\ OPEN ACCESS}

\title{
IgG4-related periarteritis in the coronary artery and subclinical pericarditis assessed the presence and monitoring of therapy response by PET and CT scan
}

\author{
Junya Matsuda, Hitoshi Takano, Wataru Shimizu
}

Department of Cardiovascular Medicine, Nippon Medical School, Tokyo, Japan

\section{Correspondence to} Junya Matsuda, jun1984087@nms.ac.jp

Accepted 18 May 2018

\section{DESCRIPTION}

A 70-year-old woman suffered from bilateral lacrimal gland enlargement from 2 years ago (figure 1). Geranium-enhanced MRI disclosed diffuse enlargement of bilateral eyelids indicating IgG4-related disease (IgG4RD), especially Mikulicz's disease. Laboratory tests showed elevation of serum IgG4 concentration and histopathological

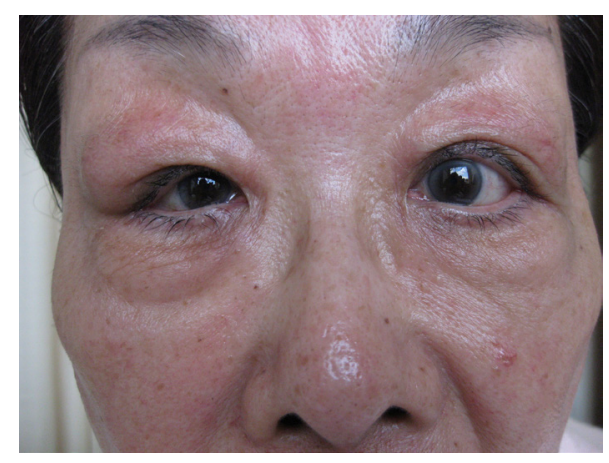

Figure 1 Bilateral lacrimal gland enlargement with predominance of right ones observed as a representative pathophysiological finding in this patient with lgG4related disease. findings of the lacrimal glands showed IgG4-positive cell infiltration and obliterated veins by inflammatory cells, which consist of lymphocytes and plasma cells (obliterative phlebitis).

Then, she was diagnosed with IgG4RD. We performed chest CT as screening for comorbidities of Mikulicz's disease. Chest CT revealed left circumflex artery (LCX) wall thickening. Coronary CT showed thickening of the left anterior descending artery and LCX. For suppressing physiological myocardial uptake, the patient was asked to restrict carbohydrate intake 24 hours before ${ }^{18}$ F-fluorodeoxyglucose (FDG) PET/CT and to consume a low carbohydrate high fat protein permitted (LCHFPP) diet for lunch of the day before the examination, a low-carbohydrate diet the night before the examination and LCHFPP diet 4 hours prior to the examination.

FDG PET/CT showed uptake in the left ventricular anterior and lateral walls, and ascending aorta (figure 2A-D, I and $\mathrm{K}$ ), indicating the comorbidity of IgG4-related periarteritis and subclinical pericarditis.

FDG uptake was also observed in lacrimal glands, retroperitoneum, pancreas and right common iliac

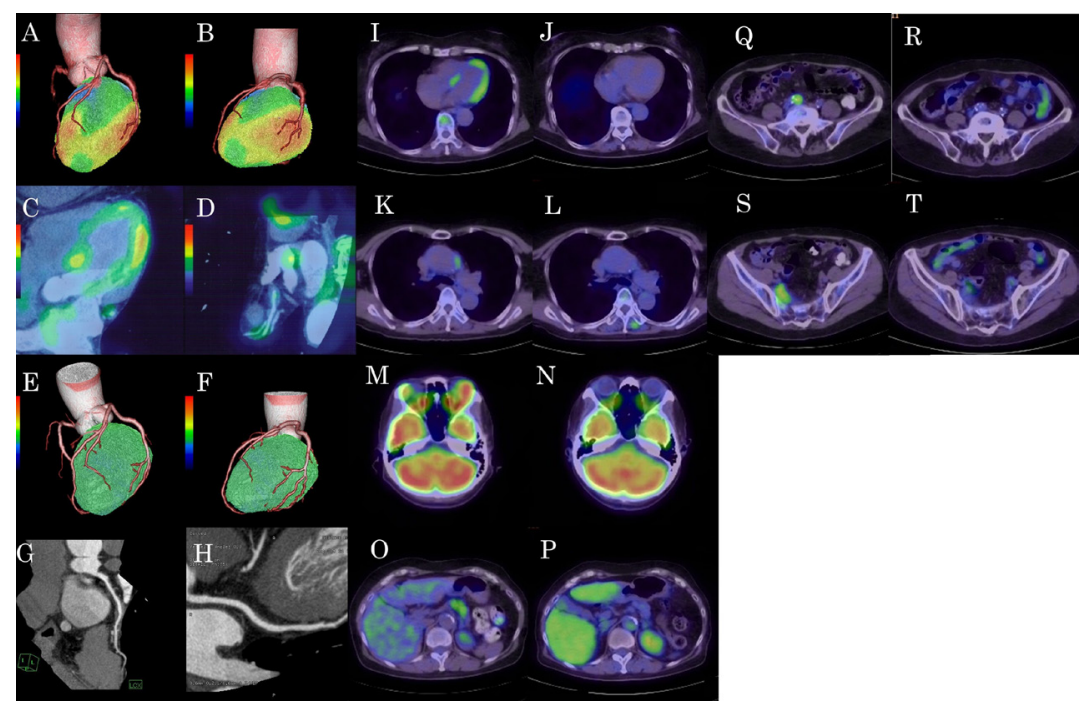

Check for updates

To cite: Matsuda J, Takano $\mathrm{H}_{\text {, }}$ Shimizu W. BMJ Case Rep Published Online First: [please include Day Month Year]. doi:10.1136/bcr-2018225172
Figure $2{ }^{18} \mathrm{~F}$-fluorodeoxyglucose (FDG) PET/CT demonstrating the distribution of IgG4-related inflammation through active uptake of FDG in the left ventricular anterior wall (A), lateral wall (B) and the intermediate lesion of left ventricular myocardium and left circumflex artery wall $(C, D)$. FDG uptake was confirmed to have disappeared by the follow-up study performed after the introduction of glucocorticoid therapy (E, F). FDG uptake was observed in the left ventricular wall, left circumflex artery wall (G) and ascending aorta (I). FDG uptake was confirmed to have disappeared in the left ventricular wall, left circumflex artery wall and ascending aorta by the follow-up study performed after the introduction of glucocorticoid therapy $(\mathrm{H}, \mathrm{J})$. 
periartery (figure $2 \mathrm{M}, \mathrm{O}, \mathrm{Q}$ and $\mathrm{S}$ ). These findings suggested IgG4-related dacryoadenitis, retroperitoneal fibromatosis, pancreatic periarteritis and right common iliac periarteritis.

Glucocorticoid therapy was started from $30 \mathrm{mg} /$ day of prednisolone. Bilateral lacrimal gland enlargement improved immediately after treatment. Serum IgG and IgG4 concentrations decreased from $2031 \mathrm{mg} / \mathrm{dL}$ and $785 \mathrm{mg} / \mathrm{dL}$, to $758 \mathrm{mg} /$ $\mathrm{dL}$ and $176 \mathrm{mg} / \mathrm{dL} 8$ weeks later. C reactive protein (CRP) concentration also decreased from $1.06 \mathrm{mg} / \mathrm{dL}$ to $0.06 \mathrm{mg} / \mathrm{dL}$. The uptake of FDG disappeared in the coronary artery and left ventricular wall, and ascending aorta (figure $2 \mathrm{E}, \mathrm{F}, \mathrm{J}$ and $\mathrm{L}$ ). Coronary $\mathrm{CT}$ revealed decrease of coronary artery wall thickening of mid-LCX from $5 \mathrm{~mm}$ (figure $2 \mathrm{G}$ ) to $3 \mathrm{~mm}$ (figure $2 \mathrm{H}$ ) after the treatment.

Furthermore, FDG PET/CT suggested improvement of dacryoadenitis, retroperitoneal fibromatosis, pancreatic periarteritis and right common iliac periarteritis (figure $2 \mathrm{~N}, \mathrm{P}, \mathrm{R}$ and $\mathrm{T}$ ).

Then the dose of prednisolone was gradually tapered, and she is now being treated as an outpatient without recurrence of the disease. FDG PET/CT provides excellent information detecting systemic involvement in patients with IgG4RD. When the disease involved the cardiovascular system, it is particularly important to make an early diagnosis since it is recently reported that IgG4-related acute myocardial infarction and pericarditis resulted in death. ${ }^{1}$ While IgG4RD often responded dramatically to glucocorticoid therapy, sometimes the therapeutic effect was partial and glucocorticoid therapy could not avoid progression of the lesions. ${ }^{2}$ Then, metabolic response assessment of glucocorticoid therapy by FDG PET/ CT was useful. FDG uptake in the IgG4-related lesions has been reported to have disappeared after steroid therapy. ${ }^{3}$ In this case, glucocorticoid therapy improved the size of the periarterial lesion and significant decrease in FDG uptake in parallel with decrease of serum IgG4 concentration. Thus, fusion images of PET/CT revealed the location of IgG4-related organs and was useful to evaluate the effect of glucocorticoid therapy for IgG4RD.

\section{Learning points}

- This study showed that fusion images of PET and CT scans (PET/CT) helped identify lgG4-related organs and were useful to evaluate the efficacy of glucocorticoid therapy for IgG4related disease.

- ${ }^{18} \mathrm{~F}$-fluorodeoxyglucose uptake of the sclerotic lesions and periarteritis decreased in accordance with improvement of the clinical condition by glucocorticoid therapy.

- A fusion imaging with the images of PET/CT was useful for identifying the location of its involvement and evaluating the effect of glucocorticoid therapy for IgG4-related disease.

Contributors JM wrote the manuscript with support from HT and WS. HT and WS supervised the findings of this work.

Funding The authors have not declared a specific grant for this research from any funding agency in the public, commercial or not-for-profit sectors.

Competing interests None declared.

Patient consent Obtained.

Provenance and peer review Not commissioned; externally peer reviewed.

Open Access This is an Open Access article distributed in accordance with the Creative Commons Attribution Non Commercial (CC BY-NC 4.0) license, which permits others to distribute, remix, adapt, build upon this work non-commercially, and license their derivative works on different terms, provided the original work is properly cited and the use is non-commercial. See: http://creativecommons.org/ licenses/by-nc/4.0/

(c) BMJ Publishing Group Ltd (unless otherwise stated in the text of the article) 2018. All rights reserved. No commercial use is permitted unless otherwise expressly granted.

\section{REFERENCES}

1 Ishizaka N, Sakamoto A, Imai Y, et al. Multifocal fibrosclerosis and IgG4-related disease involving the cardiovascular system. J Cardiol 2012;59:132-8.

2 Kasashima S, Kawashima A, Kasashima F, et al. Immunoglobulin G4-related periaortitis complicated by aortic rupture and aortoduodenal fistula after endovascular AAA repair. J Endovasc Ther 2014:21:589-97.

3 Nakamoto Y, Saga T, Ishimori T, et al. FDG-PET of autoimmune-related pancreatitis: preliminary results. Eur J Nucl Med 2000;27:1835-8.

Copyright 2018 BMJ Publishing Group. All rights reserved. For permission to reuse any of this content visit

http://group.bmj.com/group/rights-licensing/permissions.

BMJ Case Report Fellows may re-use this article for personal use and teaching without any further permission.

Become a Fellow of BMJ Case Reports today and you can:

- Submit as many cases as you like

- Enjoy fast sympathetic peer review and rapid publication of accepted articles

- Access all the published articles

- Re-use any of the published material for personal use and teaching without further permission

For information on Institutional Fellowships contact consortiasales@bmjgroup.com

Visit casereports.bmj.com for more articles like this and to become a Fellow 